Mehmet Akif Ersoy Üniversitesi Fen Bilimleri Enstitüsü Dergisi 11(2): 223-229 (2020)

The Journal of Graduate School of Natural and Applied Sciences of Mehmet Akif Ersoy University 11(2): $223-229$ (2020)

Araştırma Makalesi / Research Paper

\title{
Tereyağı Örneklerinden Laktik Asit Bakterilerinin İzolasyonu, Karakterizasyonu ve Bazı Endüstriyel Özelliklerinin Belirlenmesi
}

\author{
Gülden BAŞYIĞiT KILIÇ (D) 1*, Hacer KAÇAR ${ }^{(D 2}$ 2, Samet ÖZKAN (D)1, \\ Seher BALLI ${ }^{(D)}$, Enes SÖNMEZ ${ }^{\mathbb{D}}$ 1, Ozan ERFILIBELI iD 1 \\ ${ }^{1}$ Burdur Mehmet Akif Ersoy Üniversitesi, Mühendislik-Mimarlık Fakültesi, Burdur \\ ${ }^{2}$ Burdur Mehmet Akif Ersoy Üniversitesi, Fen Bilimleri Enstitüsü, Burdur \\ Geliş Tarihi (Received): 23.05.2020, Kabul Tarihi (Accepted): 10.09.2020 \\ $\square$ Sorumlu Yazar (Corresponding author*): gkilic@mehmetakif.edu.tr \\ (C) +902482132724 吾 +902482132704
}

ÖZ

Bu araştırmada Burdur, Afyon ve Antalya illerinde halk pazarlarından toplanan 20 adet tereyağı örneğinden izole edilen laktik asit bakterilerinin, endüstriyel tereyağı üretimi için bazı teknolojik özellikleri incelenmiştir. Araştırmada 101 adet laktik asit bakterisi izole edilmiş ve bu izolatların; sütü koagüle etme, optimum sıcaklık ve NaCl konsantrasyonunda gelişme özellikleri, diasetil üretimi, sitrat kullanımı, amilolitik ve lipolitik aktiviteleri incelenmiş, en iyi teknolojik özelliğe sahip olan suşların genetik tanısı yapılmıştır. Yapılan analizler sonucunda izolatların 70 adedi hızlı koagülasyon özelliğine sahipken, kalan 31 adet bakteri zayıf koagülasyon özellik göstermiştir. Optimum sıcaklık ve NaCl konsantrasyonu deneyleri sonucunda; izolatların \%10 tuz konsantrasyonunda ve $4^{\circ} \mathrm{C}$ 'de gelişiminin zayıf olduğu gözlemlenmiştir. İzolatların 36 adedinde diasetil üretimi belirlenmiştir. İncelenen izolatların 38 adedinde sitrat kullanımı tespit edilirken, 57 adedinde amilolitik ve19 adetinde ise lipolitik aktivite tespit edilmiştir. Teknolojik özellikler değerlendirilerek 7 adet bakteri seçilmiş ve genetik tanı testi yapılmıştır. Sonuçlara göre 1 adet Enterococcus faecalis (TY5-B), 2 adet Enterococcus faecium (TY3-3 ve TY5-1), 2 adet Lactobacillus casei (TY9-I ve TY18-4) ve 2 adet Pediococcus acidilactici (TY11-1A ve TY15-2) tanımlanmıştır.

Anahtar Kelimeler: Laktik asit bakterileri, teknolojik özellikler, tereyağı

\section{Isolation and Characterization of Lactic Acid Bacteria from Butter Samples and Determination of their Some Technological Properties}

\begin{abstract}
In this study, some technological properties of lactic acid bacteria isolated from 20 butter samples collected from the public markets in Burdur, Afyon and Antalya provinces were investigated for industrial butter production In the research, 101 lactic acid bacteria were isolated and these isolates were examined for milk coagulation, viability at optimum temperature and $\mathrm{NaCl}$ concentration, diacetyl production, utilization of citrate, amylolytic and lipolytic activity. The isolates with the best technological properties were genetically identified. As a result of the analysis, 70 of the isolates had fast coagulation properties while the remaining 31 bacteria showed weak coagulation properties. As a result of viability experiments at optimum temperature and $\mathrm{NaCl}$ concentration, weak growth of the isolates was observed at $10 \%$ salt concentration and at $4 \mathrm{C}^{\circ}$. Diacetyl production was determined in 36 of the isolates. While the citrate utilization was observed in 38 of the isolates examined, amylolytic activity was determined in 57 and lipolytic

Gülden BAŞYiĞiT KILIÇ, https://orcid.org/0000-0003-1211-0568 Hacer KAÇAR, https://orcid.org/0000-0001-5516-3091

Samet ÖZKAN, https://orcid.org/0000-0002-8823-5386

Seher BALLI, https://orcid.org/0000-0001-6516-6376

Enes SÖNMEZ, https://orcid.org/0000-0003-2725-912X

Ozan ERFiLiBELLi, https://orcid.org/0000-0002-6591-8563
\end{abstract}


activity was determined in 19 strains. According to the technological properties, 7 isolates were selected and genetically identified. In this respect, 1 strain of Enterococcus faecalis (TY5-B), 2 strains of Enterococcus faecium (TY3-3 and TY5-1), 2 strains of Lactobacillus casei (TY9-I and TY18-4) and 2 strains of Pediococcus acidilactici (TY11-1A and TY15 -2) were identified.

Keywords: Lactic acid bacteria, technological properties, butter

\section{GíRiş}

Süt ve mamulleri arasında önemli bir yeri olan tereyağı, ekonomik değeri bakımından da önemli bir süt ürünüdür. Laktik asit bakterileri (LAB)'nin gıda teknolojisinde önemli bir rolü bulunmaktadır ve gıda üretimi ve muhafazasında kullanımı insanlık tarihi kadar eskidir. Fermantasyonda rol oynayan mikroorganizmaların doğal olarak hammaddede yeterli düzeyde bulunduğu gıdalarda, fermantasyon başlatıcı kültür ilave edilmeden doğal olarak gerçekleştirilebilmesine karşın, başlatıcı kültür kullanılarak gerçekleştirilen fermantasyonlar, standart ve daha yüksek kalitede ürünlerin üretilebilmesine olanak sağlamaktadır (Holzapfel, 1997). Tereyağı üretimi genellikle başlatıcı kültürler ilave edilmeden, her zaman standart olmayan geleneksel tekniklere dayanmaktadır. Bu sebeple, fermantasyon işlemi tamamen sütten ve çevreden kaynaklanan doğal mikrobiyal floraya bağlıdır. Fermente süt ürünlerinin üretimi için kullanılan başlatıcı kültürler; koruma, organoleptik kalite ve besin değeri açısından son ürün kalitesinde önemli bir rol oynar. Ürün kalitesi üzerindeki etki, büyük ölçüde suşa bağlıdır ve suşlar arasındaki metabolik yolların varlığı ve aktivitesindeki farklılıklardan kaynaklanır (Van Hylckama Vlieg ve Hugenholtz, 2007). Geleneksel tereyağından yabani tip suşların izolasyonu, bunların tanımlanması ve özelliklerinin belirlenmesi gıda fermantasyonları için yeni başlatıcı/destek kültürleri elde etmek için izlenilen klasik bir yöntemdir (Abdelbasset ve Djamila, 2008). Seçilen bu bakteriler kullanılarak fermente gıdaların, karakteristik lezzetini ve özelliklerini kaybetmeden büyük ölçekli üretimi gerçekleştirilebilir (Ammor ve ark., 2006).

Tereyağı üretiminde kullanılan başlatıcı kültürler veya doğal florada bulunan mikroorganizmaların gelişmesi sonucu meydana gelen laktik asit, diasetil, $\mathrm{CO}_{2}$, asetoin, uçucu yağ asitleri ile ürüne özgü tat ve aroma oluşmaktadır (Bilgin ve ark. 2014). Tereyağı ve fermente süt ürünlerinde kullanılan kültürlerin aroma maddeleri ve karbondioksit oluşturma özelliklerinin yüksek olması istenmektedir. Lactococcus lactis subsp. cremoris (Lc. cremoris), Lactococcus lactis subsp. lactis biovar. diacetylactis (LC. diacetylactis)'e göre daha iyi aroma sağlamaktadır. Aroma oluşmasında rol oynayan bileşikler arasında en önemlisi diasetildir (Sağdıç ve ark., 2002). Diasetil, tereyağı gibi fermente süt ürünlerinde temel aroma maddesi olan ve yapısı kimyasal olarak asetona oldukça benzeyen, süt ürünlerinin aromasını etkileyen en önemli bileşiklerden biridir ve ürünlere tereyağına benzer bir lezzet verir (Madera ve ark., 2003; Karaca ve ark., 2010). Diasetil tereyağı, ayran ve taze peynir gibi birçok süt ürününde düşük konsantrasyonlarda gereklidir (Hugenholtz ve ark., 2000). Sitrattan diasetil sentezi için başlatıcı kültürlere diasetil üretebilen $L A B$ suşlarının eklenmesi gerekmektedir. LAB genel olarak zayıf lipolitik aktiviteye sahiptir, ancak bazı suşların esas olarak orta uzunlukta zincirlere sahip yağ asitleri içeren trigliseritleri hidrolize ettiği belirlenmiştir (Katz ve ark., 2002). Yapılan bu araştırmada halk pazarlarından tereyağı örnekleri toplanmış ve LAB izolasyonu yapılmıştır. İzolatların bazı teknolojik özellikleri belirlenmiş ve en iyi teknolojik özelliğe sahip olan suşların genetik tanısı yapılmıştır.

\section{MATERYAL VE YÖNTEM}

Araştırmada Burdur, Afyon ve Antalya illerindeki halk pazarlarından ev tipi yöntemle yapılan 20 adet tereyağı örneği toplanmıştır. Örnekler steril kaplar içerisinde ve soğuk koşullarda laboratuvara getirilmiştir.

\section{Tereyağı Örneklerinin İzolasyon için Hazırlanması}

Tereyağı örneklerinden LAB izolasyonu yapılmıştır. Bu amaçla tartılan $10 \mathrm{~g}$ tereyağı örneği $90 \mathrm{ml}$ steril $1 / 4$ ringer çözeltisi ile homojen hale getirilmiş ve $1 / 4$ steril ringer çözeltisi ile $1 / 10$ oranında seyreltilerek seri dilüsyonları hazırlanmıştır.

\section{İzolasyonda Kullanılan Besiyerleri}

Tereyağı örneklerinden Lc. diacetylactis, Lc. cremoris izolasyonu için M17 agar besiyeri (Merck), diğer LAB için $\% 0,01$ siklohekzimid ilaveli deMan, Rogosa and Sharpe (MRS) agar besiyeri kullanılmıştır (Ravula ve Shah, 1998). Ekim yapılan Petri kutuları anaerob jar içerisinde Anaerocult A mini kit (Merck) kullanılarak $42^{\circ} \mathrm{C}$ 'de 48 saat inkübe edilmiştir. İnkübasyon sonrasında izolatların koloni morfolojisi, Gram reaksiyonları ve katalaz aktiviteleri incelenmiştir (Erkkila ve Petaja, 2000). Kok ve çubuk şekilli, sporsuz, Gram pozitif, katalaz negatif olan kolonilerin saf kültürleri elde edilip stoklanmıştır (Hartemink ve ark., 1997).

\section{İzolatların Sütü Koagüle Etme Özelliklerinin Belirlenmesi}

İzolatların sütü koagüle etme özelliğinin belirlenmesi için $110^{\circ} \mathrm{C}$ 'de $10 \mathrm{dk}$ sterilize edilerek hazırlanan \%10'luk 
yağsız süt tozu besi ortamına \% 2 oranında aktif kültür aşılanarak $42^{\circ} \mathrm{C}$ 'de 36 saate kadar inkübe edilmiştir. İnkübasyonun 16.ve 36. saatlerinde ortam pH'sı ölçülmüştür. 16 saate kadar sütü koagüle eden kültürler hızlı koagülasyon özelliğine sahip olarak, 36 saate kadar sütü koagüle edemeyen suşlar ise zayıf koagülasyon özelliğine sahip olarak nitelendirilmiştir (Hebert ve ark., 2001).

\section{İzolatların Optimum Sıcaklık ve $\mathrm{NaCl}$ Konsantrasyonunda Gelişiminin Belirlenmesi}

Aktif kültürlerden steril MRS sıvı besi yerine $\% 1$ oranında inokülasyon yapılmış ve $4,15,30$ ve $45^{\circ} \mathrm{C}$ 'de 48 saat inkübe edilmiştir. Süre sonunda MRS sıvı besi yerinde bulanıklık oluşumuna göre değerlendirme yapılmıştır. Bulanıklık görülen tüpler pozitif, görülmeyenler ise negatif olarak değerlendirilmiştir. Tuz toleransı için $\% 2,6$ ve $10 \mathrm{NaCl}$ içeren MRS sıvı besi yerine izolatlar $\% 1$ oranında aşılanmıştır. Bulanıklık görülen tüpler pozitif, görülmeyenler ise negatif olarak değerlendirilmiştir (Morales ve ark., 2011; Cui ve ark., 2012).

\section{İzolatların Diasetil Üretiminin Belirlenmesi}

İolatlar $10 \mathrm{ml} \mathrm{UHT}$ süte inoküle edilmiş ve $30^{\circ} \mathrm{C}$ 'de 24 $s$ inkübe edilmiştir. Her hücre kültüründen $1 \mathrm{ml}$ alınarak, üzerine $0,5 \mathrm{ml} 1$-naphthol $(1 \% \mathrm{w} / \mathrm{v})$ (Merck) ve $\mathrm{KOH}$ solüsyonu $(16 \% \mathrm{w} / \mathrm{v})$ damlatılmış ve $30^{\circ} \mathrm{C}$ 'de 24 saat inkübe edilmiştir. Tüplerin yüzeyinde oluşan kırmızı halka diasetil oluşumu olarak değerlendirilmiştir (Franciosi ve ark., 2009).

\section{İolatların Sitrat Kullanımının Belirlenmesi}

Sitrat kullanımının belirlenmesi için kalsiyum sitrat agarda gelişen kolonilerin etrafında şeffaf zon oluşumu pozitif olarak değerlendirilmiştir (Oliszewski ve ark., 2006).

\section{İolatların Amilolitik Aktivitelerinin Belirlenmesi}

Yüzeyi kurutulmuş nişasta agar besi ortamına (Gordon ve ark., 1973) 24 saatlik kültürler inoküle edilmiş ve $30^{\circ} \mathrm{C}$ 'de 48 saat inkübasyona bırakılmıştır. İnkübasyondan sonra besi yeri üzerine iyodin solüsyonu damlatılarak 15-30 dakika bekletilmiş ve amilolitik aktivite için seffaf zon oluşumu incelenmiştir.

\section{İolatların Lipolitik Aktivitelerinin Belirlenmesi}

Test edilecek bakteriler MRS sıvı besi yerinde geliştirildikten sonra tributyrin agara inoküle edilmiştir (Leuschner ve ark., 1997). Petriler 4 gün boyunca $37^{\circ} \mathrm{C}$ 'de inkübe edilmiş ve koloni etrafında oluşan şeffaf zonun çapı (mm) ölçülmüştür.

\section{İzolatların Genetik Tanısının Yapılması}

İzolatların genomik DNA'ları ticari DNA ektraksiyon kiti (Pure Link Genomic DNA Kit, Invitrogen K) kullanılarak, kullanma kılavuzunda belirtildiği şekilde ekstrakte edilmiştir. Elde edilen DNA $30 \mu \mathrm{l}$ yıkama çözeltisi içerisinde toplanmış ve $-20^{\circ} \mathrm{C}$ 'de saklanmıştır. 16S-ITS bölgesi literatürde belirtilen EGE1/L1 primerleri kullanılarak çoğaltılmıştır. Bu amaçla; İleri primer 5'-AGAGTTTGATCCTGGCTCAG-3' (Dajonchio ve ark., 1998) ve Geri primer 5'-CAAGGCATCCACCGT-3' (Jensen ve ark., 1993) kullanıımıştır. Bu primerler 1800-2000 bp gen bölgesini çoğaltmaktadır. Polimeraz zincir reaksiyonu (PZR) $50 \mu$ lolarak hesaplanmış ve özel ince duvarlı PZR tüplerinde ve termal döngü cihazında (Bio-Rad, T100TMThermal Cycler, ABD) gerçekleştirilmiştir. PZR reaksiyonu için 1 örneğe toplamda $50 \mu$ l olacak şekilde $4 \mu \mathrm{l}$ genomik DNA, $5 \mu \mathrm{l}$ 10xreaksiyon buffer (Fermentas, Thermo Fisher Scientific, ABD), $3 \mu \mathrm{l} \mathrm{MgCl} 2$ (25mM) (Fermentas, ThermoFisherScientific, ABD), 30,70 $\mu$ steril $\mathrm{dH} 20,1 \mu \mathrm{l}$ ileri primer $(10 \mathrm{mM}), 1 \mu \mathrm{l}$ geri primer $(10$ $\mathrm{mM}$ ), $5 \mu \mathrm{l}$ dNTP karışımı (her biri $2 \mathrm{mM}$ ) (Fermentas, Thermo Fisher Scientific, ABD), $0.30 \mu \mathrm{l}$ Taq DNA polimeraz (Fermentas, Thermo Fisher Scientific, ABD) hazırlanmıştır. Bu karışımın reaksiyonu termal döngü cihazı kullanılarak; 5 dakika boyunca $94^{\circ} \mathrm{C}$ 'de, 1 dakika 40 döngüde $94^{\circ} \mathrm{C}$ 'de denatürasyon, 1 dakika $42^{\circ} \mathrm{C}$ 'de bağlanma, 1 dakika $72^{\circ} \mathrm{C}$ 'de uzama ve 10 dakika $72^{\circ} \mathrm{C}$ 'de son uzaması gerçekleştirilmiştir.16S-ITS bölgesinin belirlenemediği örneklerde ise 16S rRNA bölgesi EGE1 (5'AGAGTTTGATCCTGGCTCAG-3') ve EGE2 (5'CTACGGCTACCTTGTTACCA-3') primerleri kullanılarak çoğaltılmıştır. Bu primerler için reaksiyon termal döngü cihazında 5 dakika boyunca $94^{\circ} \mathrm{C}$ 'de, 1 dakika 40 döngüde $94^{\circ} \mathrm{C}^{\prime}$ de denatürasyon, 1 dakika $56^{\circ} \mathrm{C}$ 'de bağlanma, 1 dakika $72^{\circ} \mathrm{C}$ 'de uzama ve 10 dakika $72^{\circ} \mathrm{C}$ 'de son uzama olarak gerçekleştirilmiştir. PZR ürünleri \%1'lik agaroz jelinde yürütülmüştür. Baz büyüklüğü tespiti için 1 kb DNA ladder (Fermentas SM0311) kullanılmıştır. Toksik olmayan GelRed (Biotium) boyası ile boyanan jel, görüntüleme sisteminde (Bio-Rad, Gel Doc ${ }^{\top M}$ Ez Imager, ABD) görüntülenmiştir.

\section{Dizi Analizi}

Bakterilerin dizi analizi BM Lab. Sis.Ltd.Şti'ne yaptırılmıştır. Elde edilen elektroferogramlar FinchTV ve BioEdit software programı kullanılarak analiz edilmiş ve DNA dizileri Nucleotide Blast (URL-1, 2020) kullanılarak karşılaştırılmıştır.

\section{BULGULAR VE TARTIŞMA}

20 adet tereyağı örneğinden 101 adet LAB izole edilmiştir. İzolatların sütü koagüle etme özellikleri incelendiğinde; izolatların 70 adedi hızlı koagülasyon özelliğine 
sahipken, inkübasyon sonrası izolatların 31 adedinin 16 saatte pH'yı 6.0'nın altına düşüremediği belirlenmiş ve bu izolatlar zayıf koagülaz olarak tanımlanmıştır. 60 izolatın pH'sı 5-6 arasında tespit edilirken, 10 adet izolatın ise (TY8G, TY9H, TY14C1, TY16E, TY16F, TY18C, TY18F, TY18K, TY20B ve TY20C) pH'yı 4 ile 5 arasında düşürdükleri belirlenmiştir. Haddadin (2005) tarafından yapılan araştrımada Lactoccoccus lactis suşunun $30^{\circ} \mathrm{C}$ 'de 6 saatlik inkübasyonda en hızlı pıhtılaşmayı gösterdiği belirtilmiştir.Bir başka çalışmada ise, Iduoi ve Karam (2008) inek sütünden yapılan geleneksel tereyağından izole edilen Lactobacillus plantarum ve Lactobacillus curvatus'un en hızlı asit üretici olduğunu belirtmiştir. Joković ve ark. (2014) kaymak üretiminde kullanılan süt ve üç adet kaymak örneğinden 178 LAB izolatı elde etmiştir. Yapılan araştırmada streptokokların dört adedinin inkübasyondan 6 saat sonra pH'yı 5,30 civarına düşürdüğü belirlenmiştir. Laktokok suşlarının süt ortamında başlangıç $\mathrm{pH}$ 'sının streptokoklardan daha düşük olduğu ancak 24 saatlik inkübasyon sonunda pH'nın 4.40'a düştüğü belirlenmiştir. Araştırmada enterokok suşlarının zayıf asit üreticisi oldukları belirlenmiş ve izolatların hiçbirinin 24 saat sonunda pH'yı düşüremediği belirtilmiştir.

Optimum sıcaklık ve $\mathrm{NaCl}$ konsantrasyonu deneyleri sonucunda; \%10 tuz konsantrasyonunda ve $4^{\circ} \mathrm{C}$ de bakteri gelişiminin zayıf olduğu gözlemlenmiştir. LAB'nin yüksek tuz konsantrasyonu ve düşük sıcaklıklarda zayıf gelişme gösterdiği bilinmektedir. Yaptığımız deneylerde bu sonucu doğrulamaktadır. Yapılan testler sonucunda örneklerin 15,30 ve $45^{\circ} \mathrm{C}$ 'de tamamına yakınının iyi geliştiği belirlenmiştir. $15^{\circ} \mathrm{C}$ 'de 2 adet zayıf gelişme belirlenirken, $45^{\circ} \mathrm{C}^{\prime}$ de 1 tane zayıf gelişme tespit edilmiş, 2 adedinde ise gelişme olmadığı görülmüştür. $4^{\circ} \mathrm{C}$ 'de bakterilerin yaklaşık \%52'si zayıf gelişme gösterirken, \%47'si gelişememiştir. Bakteriler \%2 ve $6 \mathrm{NaCl}$ konsantrasyonunda iyi gelişme göstermişlerdir; ancak $\% 10 \mathrm{NaCl}$ konsantrasyonunda yaklaşık \%41'i zayıf gelişme gösterirken, \%32'sinin \%10 NaCl'yi tolere edemedikleri tespit edilmiştir. Idoui ve Karam (2008) tarafından yapılan araştırmada geleneksel tereyağından elde edilen 26 izolattan Gram pozitif basil olanlardan 21 tanesi $15^{\circ} \mathrm{C}$ 'de gelişirken, hiçbiri $45^{\circ} \mathrm{C}$ 'de ve $\% 6,5$ tuz oranında gelişememiştir. Gram pozitif kok olan 4 izolatın ise $10^{\circ} \mathrm{C}$ 'de gelişebildiği ancak $45^{\circ} \mathrm{C}$ ve $\% 6,5$ tuz konsantrasyonunda gelişemedikleri belirlenmiştir.

Bakterilerin diasetil oluşumunun belirlenmesi için yapılan deneyde 101 izolatın 6 adedinde yoğun gelişme, 6 adedinde normal gelişme, 24 adedinde ise zayıf gelişme tespit edilirken, 65 adedinde diasetil üretimi tespit edilmemiştir. Diasetil belirli LAB tarafından üretilen sitrat metabolizması ürünü olan uçucu bir bileşiktir ve lezzet oluşumuna doğrudan katkıda bulunması sebebiyle endüstriyel üretimde bakterilerde aranan önemli bir özelliktir (Rincon-Delgadillo ve ark., 2012). Ribeiro ve ark. (2013) yaptıkları araştırmada, Lc. lactis'in en yüksek diasetil üreticisi olduğunu, 4 Enterococcus suşunun orta seviyede diasetil üretirken, sadece bir Enterococcus suşunda (L3A1M3) diasetil üretiminin tespit edilmediğini belirtmişlerdir.

İncelenen izolatların 38 adedinde sitrat kullanımı, 57 adedinde ise amilolitik aktivite tespit edilmiştir. Joković ve ark. (2014) tarafından yapılan çalışmada, kaymak üretiminde kullanılan süt ve üç adet kaymak örneğinden 178 LAB izole edilmiştir. Araştırmada incelenen Lc. lactis ve Streptococcus salivarius subsp. thermophilus suşları iyi asidifikasyon ve proteolitik özellik gösterirken, $L e$ uconostoc mesenteroides suşlarının sitratı metabolize edebildiği ve endüstriyel kaymak üretiminde başlatıcı kültür olarak kullanılabilecekleri belirtilmiştir. Araştırmamızda amilolitik aktivite, incelenen 101 izolattan 57 adedinde belirlenmiştir. İncelenen 44 izolatta amilolitik akitivitenin tespit edilememesi, bu izolatların nişasta substratlarının sakkarifikasyonunda ve sıvılaştırılmasında etkili olmadıkları şeklinde açıklanabilir (Mechai ve ark., 2014). Bakterilerin lipolitik aktiviteleri incelendiğinde 82 izolatta lipolitik aktivite tespit edilmezken, sadece 19 adedinde lipolitik aktivite belirlenmiştir. Lipoliz, lipidlerin lipaz gibi lipolitik enzimlerin etkisi ile gliserin ve yağ asitlerine hidrolize edildiği işlemdir. LAB'nin lipaz aktivitesi, cinse ve türe göre değişir. Süt, yoğurt ve tereyağı gibi ürünlerde lipolitik aktivite çok istenmese de, bazı peynir türlerinde aroma ve yapı oluşumu açısından belirli bir lipoliz seviyesi istenir (Yerlikaya, 2019). Fermente süt ürünlerinde LAB'nin diğer mikroorganizma gruplarına kıyasla genellikle zayıf lipolitik olduğu düşünülmektedir (Papamanoli ve ark., 2003; Mechai ve ark., 2014). Ammor ve ark. (2006) tarafından yapılan araştırmada da Lactobacillus suşlarının çoğunda lipolitik akitivite belirlenmemiştir. Bettache ve ark. (2012), Cezayir'in batı bölgesinden topladıkları 5 adet tereyağ örneğinden 76 adet LAB izole etmişlerdir. İncelenen izolatlardan sadece 1'er adet Lactobacillus delbrueckii subsp. delbrueckii ve Lactobacillus delbrueckii subsp. bulgaricus suşunda lipolitik aktivite tespit edilmiştir. 
Tablo 1. Genetik tanısı yapılmış bakterilerin örneklerinin alındığı şehirler, tanımlama güvenilirliği, kullanılan primerler ve nükleotid dizi erişim numaraları

\begin{tabular}{|c|c|c|c|c|}
\hline Bakteriler & $\begin{array}{c}\text { Örneğin Alındığı } \\
\text { Şehir }\end{array}$ & $\begin{array}{c}\text { Tanımlama Güvenilir- } \\
\text { liği }\end{array}$ & Kullanılan Primer Çifti & $\begin{array}{c}\text { Nükleotid Dizi Erişim } \\
\text { Numarası }\end{array}$ \\
\hline Ent. faecium TY3-3 & Antalya & 99 & $\overline{E 1 / L 1}$ & MK007100 \\
\hline Ent. faecalis TY5-B & Burdur & 100 & $\mathrm{E} 1 / \mathrm{L} 1$ & MK007103 \\
\hline Ent. faecium TY5-1 & Afyonkarahisar & 100 & E1/L1 & MK007101 \\
\hline L. casei TY9-I & Burdur & 99 & $\mathrm{E} 1 / \mathrm{L} 1$ & MK007102 \\
\hline P. acidilactici TY11-1A & Burdur & 100 & $\mathrm{E} 1 / \mathrm{L} 1$ & MH879585 \\
\hline P. acidilactici TY15-2 & Burdur & 99 & $\mathrm{E} 1 / \mathrm{L} 1$ & MH879582 \\
\hline L. casei TY18-4 & Burdur & 99 & $\mathrm{E} 1 / \mathrm{L} 1$ & MK007104 \\
\hline
\end{tabular}

Tablo 2. Genetik tanısı yapılmış bakterilerin farklı sıcaklık, tuz konsantrasyonunda gelişme ve koagülasyon özellikleri

\begin{tabular}{|c|c|c|c|c|c|c|c|c|}
\hline Bakteriler & $15^{\circ} \mathrm{C}$ & $30^{\circ} \mathrm{C}^{\prime}$ & $45^{\circ} \mathrm{C}^{\prime}$ & $\% 2 \mathrm{NaCl}$ & $\% 6 \mathrm{NaCl}$ & $\% 10 \mathrm{NaCl}$ & $\begin{array}{c}\mathrm{pH} \\
16 \mathrm{~s}\end{array}$ & $\begin{array}{c}\mathrm{pH} \\
32 \mathrm{~s}\end{array}$ \\
\hline $\begin{array}{l}\text { Ent. faecium } \\
\text { TY3-3 }\end{array}$ & + & + & + & + & + & $\overline{Z G}$ & 5,31 & 5,03 \\
\hline $\begin{array}{l}\text { Ent. faecalis } \\
\text { TY5-B }\end{array}$ & + & + & + & + & + & + & 5,94 & 5,28 \\
\hline $\begin{array}{l}\text { Ent. faecium } \\
\text { TY5-1 }\end{array}$ & + & + & + & + & + & - & 5,20 & 5,03 \\
\hline L. casei TY9-I & + & + & + & + & + & + & 5,49 & 4,67 \\
\hline $\begin{array}{l}P . \text { acidilactici } \\
\text { TY11-1A }\end{array}$ & + & + & + & + & + & $Z G$ & 5,43 & 5,03 \\
\hline $\begin{array}{l}\text { P. acidilactici } \\
\text { TY15-2 }\end{array}$ & - & + & - & + & + & $Z G$ & 5,19 & 5,10 \\
\hline $\begin{array}{l}\text { L. casei TY18- } \\
4\end{array}$ & + & + & + & + & + & $Z G$ & 5,12 & 5,09 \\
\hline
\end{tabular}

(Z.G): Zayıf Gelişme, (+): Gelişme var, (-): Gelişme yok

Tablo 3. Genetik tanısı yapılmış bakterilerin diasetil üretimi, lipolitik, amilolitik aktivite ve sitrat kullanım özellikleri

\begin{tabular}{|l|c|c|c|c|}
\hline \multicolumn{1}{|c|}{ Bakteri adı } & Diasetil Üretimi & $\begin{array}{c}\text { Lipolitik Aktivite } \\
(\mathbf{m m})\end{array}$ & $\begin{array}{c}\text { Amilolitik Aktivite } \\
\text { Kullanımı }\end{array}$ \\
\hline Ent. faecium TY3-3 & - & 19,06 & + & - \\
\hline Ent. faecalis TY5-B & +++ & - & + & - \\
\hline Ent. faecium TY5-1 & +++ & 19,69 & + & + \\
\hline L.casei TY9-I & +++ & - & + & + \\
\hline P. acidilactici TY11-1A & +++ & - & + & + \\
\hline P. acidilactici TY15-2 & + & - & + & + \\
\hline L.casei TY18-4 & ++ & - & + \\
\hline
\end{tabular}

$(-)$ : Gelişme yok, (+): Gelişme var, (++): Normal gelişme, (+++): Yoğun gelişme 
Yapılan deneyler sonucunda farklı özellikler gösteren 7 adet izolat seçilip genetik tanı testi yapılmıştır. Genetik tanı sonuçlarına göre seçilen izolatlar Enterococcus faecalis TY5-B, Enterococcus faecium TY3-3, TY5-1 Lactobacillus casei TY9-I ve TY18-4 ve Pediococcus acidilactici TY11-1A, TY15-2 olarak tanımlanmıştır. Tanımlanan bakterilerin özellikleri Tablo 1, 2 ve 3'de belirtilmiştir. Bettache ve ark. (2012)'nın izole ettiği 76 adet LAB içerisinde baskın floranın Lactobacillus, Lactococcus ve $L e$ uconostoc olduğu belirlenmiştir. Tanımlanan diğer gruplar piyogenik streptokok ve enterokoklardır. Baskın laktokok türleri Lc. lactis olarak tespit edilirken, Leuconostoc'ların \%83'ü Leuconostoc mesenteroides subsp. dextranicum olarak belirlenmiştir. Tanımlanan diğer bakteriler ise Leuconostoc citreum, Leuconostoc lactis, Lactobacillus delbrueckii subsp. lactis ve L. plantarum'dur. Jokovićve ark. (2014)'nın araştırmasında, süt örneklerinde $L c$. lactis ve Ent.faecium baskın olarak bulunurken, kaymak örneklerinde Leu. mesenteroides ve Enterococcus durans'ın baskın olduğu belirlenmiştir. Mourad ve Bettache (2018) tarafından yapılan araştırmada ise, Kuzey Cezayir'in Djelfa bölgesinden toplanan 5 adet tereyağı örneğinden izole edilen 177 adet izolattan 79 adet LAB tanımlamışlardır. Araştırma sonunda en baskın bulunan türler Lactobacillus alimentarius $(\% 15,19)$, L. plantarum $(\% 22,78)$, Lactobacillus fermentum $(\% 18,99)$, Lactobacillus brevis $(\% 6,33)$, Lc. lactis $(\% 12,66)$, Lc. cremoris $(\% 6,33)$, Leu. mesenteroides $(\% 6,33)$ ve Ent. faecalis $(\% 11,39)$ olarak belirlenmiştir. Enterokokların patojenisitesine ilişkin kaygılara rağmen, son çalışmalar gıda ve et enterokoklarının, özellikle Ent.faecium'un klinik suşlardan çok daha düşük bir patojenite potansiyeline sahip olduğunu göstermektedir (Hugas ve ark. 2003).

Yapılan bu araştırmada halk pazarlarından toplanan tereyağı örneklerinden izole edilen LAB'nin bazı teknolojik özellikleri belirlenmiş ve en iyi teknolojik özelliğe sahip olan suşların genetik tanısı yapılmıştır. Bu çalışmada teknolojik özellikleri belirlenmiş olan L. casei TY9-I, TY18-4 ve $P$. acidilactici TY11-1A, TY15-2 suşlarının farklı tereyağların üretiminde kullanılacağı yeni araştırmaların planlanması önemlidir. Yapılacak yeni araştırmalarla teknolojik özellikleri incelenmiş olan diğer izolatların genetik tanısının yapılması ve LAB'nin endüstriyel uygulamalarda önemli olan diğer teknolojik özelliklerinin belirlenmesi planlanmaktadır.

\section{TEŞEKKÜR}

Bu çalışma 2018 yılı TÜBITAK 2209-A Üniversite Öğrencileri Araştırma Projeleri Destekleme Programı tarafından desteklenmiştir.

\section{KAYNAKLAR}

Abdelbasset, M., Djamila, K. (2008). Antimicrobial activity of autochthonous lactic acid bacteria isolated from Algerian traditional fermented milk "Raïb". African Journal of Biotechnology. 7: 2908-2914.

Ammor, S., Tauveron, G., Dufour, E., Chevallier, I. (2006). Antibacterial activity of lactic acid bacteria against spoilage and pathogenic bacteria isolated from the same meat small-scale facility: 1 - screening and characterization of the antibacterial compounds. Food Control. 17: 454-461.

Bettache, G., Fatma, A., Miloud, H., Mebrouk, K. (2012). Isolation and identification of lactic acid bacteria from Dhan, a traditional butter and their major technological traits. World Applied Sciences Journal. 17(4): 480-488.

Bilgin, M., Kırbaşlar, Ş., Özcan, Ö., Dramur, U. (2014). Bütirik asidin ekstraksiyonunda çözücü seçimi. 6. Ulusal Kimya Mühendisliği Kongresi, UKMK-6. İzmir, Türkiye.

Cui, F., Wan, C., Li, Y., Liu, Z., Rajashekara, G.B. (2012). Coproduction of lactic acid and Lactobacillus rhamnosus cells from whey permeate with nutrient supplements. Food Bioprocess Technology. 5: 1278-1286.

Dajonchio, D., Borin, S., Consolandi, A., Mora, D., Manachini, P.L., Sorlini, C. (1998). 16S-23S rRNA internal transcribed spacers as molecular markers for the species of the $16 \mathrm{~S}$ rRNA group of the genus Bacillus. FEMS Microbiology Letters. 163: 229-236.

Erkkila, S., Petaja, E. (2000). Screening of commercial meat starter cultures at low $\mathrm{pH}$ and in the presence of bile salts for potential probiotic use. Meat Science. 55: 297-300.

Franciosi, E., Settanni, L., Cavazza, A., Poznanski, E. (2009). Biodiversity and technological potential of wild lactic acid bacteria from raw cows' milk. International Dairy Journal. 19(1): 3-11.

Gordon, R. E., Haynes, W. C., Pang, C. H.N. (1973). The Genus Bacillus. Washington, D.C. United States Department of Agriculture.

Hartemink, R., Van Laere, K.M.J., Rombouts, F.M. (1997). Growth of enterobacteria on fructo-oligosaccharides. Journal of Applied Microbiology. 83: 367-374.

Hebert, E.M., De Gırı, G.,Raya, R. (2001).Isolation and characterization of a slowly milk-coagulating variant of Lactobacillus helveticus deficient in purine biosynthesis. Applied and Environmental Microbiology. 1846-1850.

Hugas, M., Garriga, M., Aymerich, M.T. (2003). Functionality of enterococci in meat products. International Journal of Food Microbiology. 88(2-3): 223-233.

Hugenholtz, J., Kleerebezem, M., Starrenburg, M., Delcour, J., De Vos, W., Hols, P. (2000). Lactococcus lactis as a cell factory for high-level diacetyl production. Applied and Environmental Microbiology. 66 (9): 4112-4114.

Holzapfel, W. (1997). Use of starter cultures in fermentation on a household scale. Food Control. 8: 241-258.

Idoui, T., Karam, N. (2008). Lactic acid bacteria from Jijel's traditional butter: isolation, identification and major technological traits. Grasas Y Aceites. 59(4): 361-367.

Jensen, M.A., Webster, J.A., Straus, N. (1993).Rapid identification of bacteria on the basis of polymerase chain reaction-amplified ribosomal DNA spacer polymorphisms. Applied and Environmental Microbiology. 945-95.

Joković, N., Rajković, J., Veljović, K., Tolinački, M., Topisirović, L. (2014). Screening of lactic acid bacteria isolated from 
Tereyağı Örneklerinden Laktik Asit Bakterilerinin İzolasyonu, Karakterizasyonu ve Bazı Endüstriyel Özelliklerinin Belirlenmesi

Serbian kajmak for use in starter cultures. Biologica Nyssana. 5(1): 37-46.

Karaca, H., Dincer, E., Merih, K. (2010). Metabolik mühendisliğinde laktik asit bakterileri. Akademik Gıda. 8(1): 32-38.

Katz, M., Medina, R., Gonzalez, S., Oliver, G. (2002). Esterolytic and lipolytic activities of lactic acid bacteria isolated from ewe's milk and cheese. Journal of Food Protection. 65: 1997-2001.

King, N. (1948). Modification of the voges-proskauer test for rapid colorimetric determination of acetylmethyl carbinol plus diacetyl in butter cultures. Dairy Industry. 13: 860-866.

Leuschner, R.G., Kenneally, P.M., Arendt, E.K. (1997). Method for the rapid quantitative detection of lipolytic activity among food fermenting microorganisms. International Journal of Food Microbiology. 37: 237-240.

Madera, C., Garcia, P., Janzen, T., Rodriquez, A., Suarez, JE. (2003). Characterisation of technologically proficient wild Lactococcus lactis strains resistant to phage infection. International Journal of Food Microbiology. 86: 213-222.

Mechai, A., Debabza, M., Kirane, D. (2014). Screening of technological and probiotic properties of lactic acid bacteria isolated from Algerian traditional fermented milk products. International Food Research Journal. 21(6): 2451-2457.

Morales, F., Morales, J., Hernández, C., Hernández-Sánchez, $H$. (2011). Isolation and partial characterization of halotolerant lactic acid bacteria from two Mexican cheeses. Applied Biochemistry and Biotechnology. 164: 889-905.

Mourad, G., Bettache, G. (2018). Characterization of lactic acid bacteria isolated from traditional butter produced in Djelfa province of Algeria. Biosciences Biotechnology Research Asia. 15(3): 737-746.

Oliszewski, R.,González, SN., Pérez Chaia, AB. (2006). Identification and technological characterization of lactic acid bacteria isolated from goat milk and artisanal cheeses of the Argentine Northwest. Revista Argentina de Lactología. 24: 47-58.

Papamanoli, E., Tzanetakis, N., Litopoulou-Tzanetaki, E., Kotzekidou, P. (2003). Characterization of lactic acid bacteria isolated from a Greek dry fermented sausage in respect of their technological and probiotic properties. Meat Science. 65: 859-867.

Ravula, R.R., Shah, N.P. (1998). Selective enumeration of Lactobacillus casei from yogurts and fermented milk drinks. Biotechnology Techniques. 12: 819-822.

Ribeiro, S.C., Coelho1, M.C., Todorov, S.D., Franco, B.D.G.M., Dapkevicius M.L.E., Silva C.C.G. (2013).Technological properties of bacteriocin-producing lactic acid bacteria isolated from pico cheese an artisanal cow's milk cheese. Journal of Applied Microbiology. 116: 573-585. Rincon-Delgadillo, M. I., Lopez-Hernandez, A., Wijaya, I., Rankin, S. A. (2012). Diacetyl levels and volatile profiles of commercial starter distillates and selected dairy foods. Journal of Dairy Science. 95(3): 1128-1139.

Sağdıç, O., Arıcı, M., Şimşek, O. (2002). Selection of starters for a traditional Turkish yayık butter made from yoghurt. Food Microbiology. 19: 303-312.

URL-1 (2020). http://blast.ncbi.nlm.nih.gov (Erişim Tarihi: 22.05.2020)

Van Hylckama Vlieg, J.E.T., Hugenholtz, J. (2007). Mining natural diversity of lactic acid bacteria for flavour and health benefits. International Dairy Journal. 17(11): 1290-1297.

Yerlikaya, O. (2019). Probiotic potential and biochemical and technological properties of Lactococcus lactis ssp. lactis strains isolated from raw milk and kefir grains. Journal of Dairy Science. 102: 1. 